\title{
PENGARUH PENGGUNAAN LEAFLET TERHADAP PENGETAHUAN SWAMEDIKASI MAHASISWA DI UNIVERSITAS MULAWARMAN
}

\author{
Lefinia Putri Pirade ${ }^{1, *}$, Welinda Dyah Ayu ${ }^{1,2}$, Jaka Fadraersada ${ }^{1,2}$ \\ ${ }^{1}$ Laboratorium Penelitian dan Pengembangan Kefarmasian "Farmaka Tropis", \\ Fakultas Farmasi, Universitas Mulawarman, Samarinda, Indonesia \\ ${ }^{2}$ Kelompok Bidang Ilmu Farmasi Klinik dan Komunitas, Fakultas Farmasi, \\ Universitas Mulawarman, Samarinda, Indonesia \\ *Email: lefiniap@gmail.com
}

\begin{abstract}
ABSTRAK
Mahasiswa merupakan kalangan pelajar yang berpendidikan tinggi serta mempunyai tingkat pengetahuan yang lebih luas jika dibandingkan dengan masyarakat pada umumnya. Dengan semakin tingginya tingkat pengetahuan dapat menimbulkan kecenderungan untuk lebih sering melakukan swamedikasi daripada orang lain. Penelitian ini dilakukan untuk mengetahui pengaruh leaflet terhadap tingkat pengetahuan swamedikasi pada mahasiswa kesehatan dan non kesehatan. Metode pengambilan data dilakukan secara prospektif dengan cara Purposive Sampling. Instrumen dalam penelitian ini berupa kuesioner pengetahuan tentang swamedikasi dan leaflet sebagai media edukasi. Disimpulkan bahwa hasil pretest mahasiswa kesehatan angkatan 2016 adalah 12,27 dan posttest 16,06 (P-value 0,000), untuk angkatan 2017 memiliki hasil pretest 11,73 dan posttest 15,00 (P-value 0,000) sedangkan mahasiswa non kesehatan angkatan 2016 mempunyai nilai pretest sebesar 15,07 dan posttest 16,50 dan memiliki P-value 0,000 sedangkan untuk angkatan 2017 dengan hasil pretest 14,57 dan posttest 16,53 (P-value 0,000). Masing-masing mahasiswa dari fakultas kesehatan dan non kesehatan mengalami perubahan tingkat pengetahuan yang signifikan setelah diberikan leaflet karena memiliki P-value >0,005.
\end{abstract}

Kata Kunci :swamedikasi, pengetahuan, leaflet, edukasi

\begin{abstract}
College students have the highest education among the other students and have a broader level of knowledge compared to the general community, these factors can lead to a tendency to do self-medication more often than the others. The purpose of this study isto see the effectof leaflet for the level of knowledge about self-medication to health and nonhealth students. The data collection method is carry out prospectively by purposive sampling. The instrument in this study was a questionnaire of knowledge about selfmedication and leaflet as an educational media. The results shows that the 2016 pretest of health students were 12.27 and posttest 16.06 ( P-value 0,000), for the 2017 class had the results of pretest 11.73 and posttest 15.00 ( $P$-value 0,000) while non-health students in 2016 had the pretest value was 15.07 and posttest 16.50 ( $P$-value 0,000) while for the 2017 class the results of pretest 14.57 and posttest 16.53 had a P-value 0,000). Student's
\end{abstract}


knowledge about self-medication is increase from both faculty categories after leaflet was given with $P$ value $<0.05$.

Keywords : self-medication, leaflet, knowledge, education

DOI: https://doi.org/10.25026/mpc.v8i1.315

\section{PENDAHULUAN}

Swamedikasi atau pengobatan sendiri merupakan bagian dari upaya masyarakat menjaga kesehatannya sendiri. Pada pelaksanaanya, swamedikasi /pengobatan sendiri dapat menjadi masalah terkait obat (Drug Related Problem) akibat terbatasnya pengetahuan mengenai obat dan penggunaannya ${ }^{[1]}$. Dasar hukum swamedikasi adalah peraturan Menteri Kesehatan No. 919 Menkes/Per/X/1993. Swamedikasi merupakan salah satu upaya yang sering dilakukan oleh seseorang dalam mengobati gejala sakit atau penyakit yang sedang dideritanya tanpa terlebih dahulu melakukan konsultasi kepada dokter [2]. Pengobatan sendiri (self medication) merupakan upaya yang paling banyak dilakukan masyarakat untuk mengatasi keluhan atau gejala penyakit sebelum mereka memutuskan mencari pertolongan ke pusat pelayanan kesehatan/petugas kesehatan ${ }^{[3]}$.

Swamedikasi sedapat mungkin harus memenuhi kriteria penggunaan obat yang rasional. Kriteria obat rasional antara lain ketepatan pemilihan obat, ketepatan dosis obat, tidak adanya efek samping, tidak adanya kontraindikasi, tidak adanya interaksi obat, dan tidak adanya polifarmasi ${ }^{[4]}$. Sampai saat ini di tengah masyarakat seringkali dijumpai berbagai masalah dalam penggunaan obat diantaranya ialah kurangnya pemahaman tentang penggunaan obat tepat dan rasional, penggunaan obat bebas secara berlebihan, serta kurangnya pemahaman tentang cara menyimpan dan membuang obat dengan benar. Sedangkan tenaga kesehatan masih dirasakan kurang memberikan informasi yang memadai tentang penggunaan obat ${ }^{[5]}$. Oleh karena itu, sebagai pelaku self-medication harus mampu mengetahui jenis obat yang diperlukan, kegunaan dari tiap obat, menggunakan obat dengan benar (cara, aturan pakai, lama pemakaian), mengetahui efek samping obat yang digunakan dan siapa yang tidak boleh menggunakan obat tersebut ${ }^{[6]}$.

Mahasiswa merupakan salah satu pelaku swamedikasi dan merupakan kalangan pelajar yang berpendidikan tinggi serta mempunyai tingkat pengetahuan yang lebih luas jika dibandingkan dengan masyarakat pada umumnya. Dengan semakin tingginya tingkat pengetahuan dapat menimbulkan kecenderungan untuk melakukan swamedikasi terhadap penyakit atau keluhan yang ringan. Penelitian mengenai swamedikasi di kalangan mahasiswa pernah dilakukan baik di Indonesia maupun di luar negeri. Salah satu penelitian yang dilakukan di Uni Emirat Arab menunjukkan bahwa sebesar 96,6\% mahasiswa farmasi melakukan swamedikasi ${ }^{[7]}$. Penelitian lain di Uni Emirat Arab yang dilakukan di universitas yang sama, namun dilakukan pada mahasiswa non kesehatan menunjukkan prevalensi swamedikasi sebesar $59 \%{ }^{[8]}$. Penelitian yang terbaru di Saudi Arabia menunjukkan bahwa prevalensi swamedikasi di kalangan mahasiswa cukup tinggi yaitu $64,8 \%$. Penelitian yang dilakukan di Indonesia adalah penelitian yang dilakukan Azali ${ }^{[8]}$ Swamedikasi yang tidak sesuai aturan 
akan menyebabkan efek yang serius seperti timbulnya reaksi efek samping obat dan resistensi antibiotik.

Berdasarkan uraian tersebut, dilakukan penelitian untuk mengetahui tingkat pengetahuan mahasiswa dalam melakukan tindakan swamedikasi, baik dari pemilihan obat maupun sumber informasi yang diperoleh serta tingkat pengetahuan terhadap tindakan swamedikasi yang dilakukan oleh mahasiswa Universitas Mulawarman Samarinda melalui edukasi dengan media leaflet.

\section{METODE PENELITIAN}

Metode penelitian ini menggunakan metode Quasy Eksperimental dengan pengambilan data secara kualitatif dimana kuesioner merupakan data primer. Sumber data berupa pretest dan posttest group yaitu dengan data hasil kuisioner. Dalam hal pengambilan data dilakukan sebanyak 2 kali (pre dan post) pada setiap responden, untuk mengetahui peningkatan pengetahuan responden tentang swamedikasi. Sebanyak 60 mahasiswa kesehatan yang terdiri dari 30 orang laki-laki dan 30 orang perempuan untuk menjadi responden diambil dari angkatan 2016 dan 2017 begitu pula dari fakultas non kesehatan sehingga terdapat 120 responden.

Variabel dari penelitian ini merupakan variabel bebas, yaitu pemberian leaflet tentang swamedikasi, dan variabel terikat meliputi pengetahuan mahasiswa Universitas Mulawarman terkait swamedikasi yang dilakukan selanjutnya data tersebut dibuat rata-rata perbandingan pertanyaan yang dijawab dengan benar dari hasil sebelum pemberian edukasi dengan leaflet dan sesudah pemberian edukasi dengan leaflet.

\section{HASIL DAN PEMBAHASAN}

Penelitian ini dilakukan di Universitas Mulawarman Samarinda, Kalimantan Timur. Responden yang dikumpulkan pada penelitian ini berasal dari fakultas dan angkatan yang berbeda dan jumlah responden laki-laki maupun perempuan di setiap fakultas ataupun angkatan telah ditentukan sehingga hasil karakteristik tidak ada kelompok responden yang lebih mendominasi dalam penelitian ini.

Tabel 1. Perbedaan Tingkat Pengetahuan tentang Swamedikasi pada Mahasiswa Universitas Mulawarman Jurusan Kesehatan

\begin{tabular}{llll}
\hline Jurusan Kesehatan & Pre & Post & SD \\
\hline Angkatan 2016 & 15,07 & 16,50 & 1,906 \\
Angkatan 2017 & 14,57 & 16,53 & 2,157 \\
Nilai P & 0,000 & 0,000 & \\
& Ada perbedaan & Ada perbedaan & \\
Kesimpulan & signifikan & signifikan & \\
\hline
\end{tabular}

Tabel 2. Perbedaan Tingkat Pengetahuan tentang Swamedikasi pada Mahasiswa Universitas Mulawarman Jurusan non Kesehatan

\begin{tabular}{llll}
\hline Jurusan Non Kesehatan & Pre & Post & SD \\
\hline Angkatan 2016 & 12,27 & 16,06 & 1,837 \\
Angkatan 2017 & 11,73 & 15,00 & 2,490 \\
Nilai P & 0,000 & 0,000 & \\
& Ada perbedaan & Ada perbedaan & \\
Kesimpulan & signifikan & signifikan & \\
\hline
\end{tabular}


Berdasarkan Tabel 1 dan Tabel 2 terlihat perbandingan nilai pretest (sebelum diberikan edukasi) dan posttest (sesudah diberikan edukasi) yang di dapatkan dari total jawaban yang benar dari masing-masing mahasiswa dan pada nilai posttest menunjukkan adanya kenaikan jumlah jawaban benar jika dibandingkan dengan nilai pretest. Pengetahuan merupakan domain yang sangat penting untuk terbentuknya tindakan seseorang ${ }^{[9]}$. Pada tabel diatas juga terlihat perbandingan tingkat pengetahuan mahasiswa kesehatan dan non kesehatan sewaktu menjawab pertanyaan kuesioner saat sebelum membaca leaflet maupun sesudah membaca leaflet. Mahasiswa kesehatan memiliki jumlah jawaban benar yang lebih banyak jika dibandingkan dengan non kesehatan (Tabel 2 dan 3). Hasil penelitian ini sama dengan hasil penelitian dari $\mathrm{Silva}^{[\mathbf{1 0 ]}}$ yang menyatakan bahwa mahasiswa kesehatan memiliki pengetahuan yang lebih tinggi daripada mahasiswa non kesehatan.

Pada tabel 2 terlihat juga perbedaan tingkat pengetahuan antara angkatan 2016 dan 2017 untuk mahasiswa kesehatan, tingkat pengetahuan angkatan 2016 lebih tinggi dibanding angkatan 2017. Hal ini sejalan dengan penelitian yang dilakukan oleh Lela dan Febryrery yang mengatakan bahwa semakin tinggi tingkat semester maka semakin tinggi pula pengetahuan yang dimiliki oleh mahasiswa kesehatan, hal yang sama juga terjadi pada responden non kesehatan dimana angkatan 2016 memiliki tingkat pengetahuan yang lebih baik jika dibandingkan dengan angkatan 2017. Usia merupakan variabel yang selalu diperhatikan dalam penelitian- penelitian epidemiologi yang merupakan salah satu hal yang mempengaruhi pengetahuan ${ }^{[11]}$ apabila dihubungkan dengan penelitian yang telah dilakukan maka dapat disimpulkan bahwa semakin bertambahnya usia, maka akan semakin banyak pengalaman yang dimiliki oleh mahasiswa baik mahasiswa kesehatan maupun non kesehatan, semakin banyak informasi yang diperoleh dan semakin memahami bagaimana cara melakukan swamedikasi. Selain itu terlihat pula pengaruh pemberian leaflet sebagai media edukasi untuk swamedikasi dengan P-value yang didapatkan yaitu $(0,000)<$ 0,005 yaitu artinya mengalami perubahan tingkat pengetahuan yang signifikan setelah pemberian edukasi karena nilai $\mathrm{P}$ yang didapatkan lebih kecil daripada 0,005 .

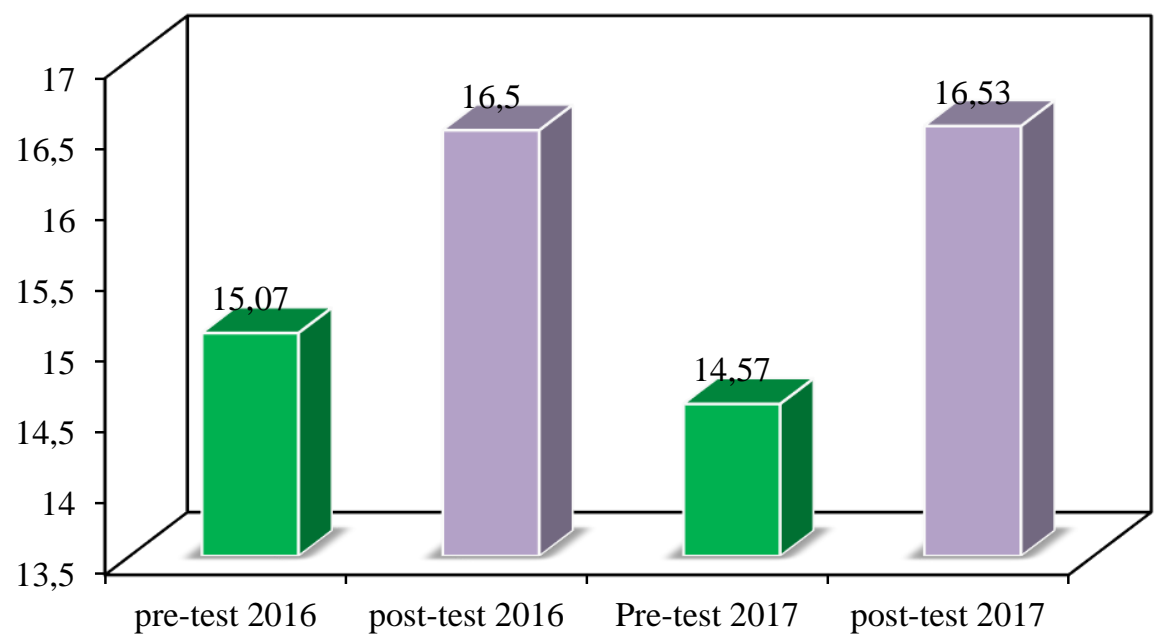

Gambar 1. Perbandingan Tingkat Pengetahuan Mahasiswa Kesehatan Sebelum dan Sesudah Membaca Leaflet 


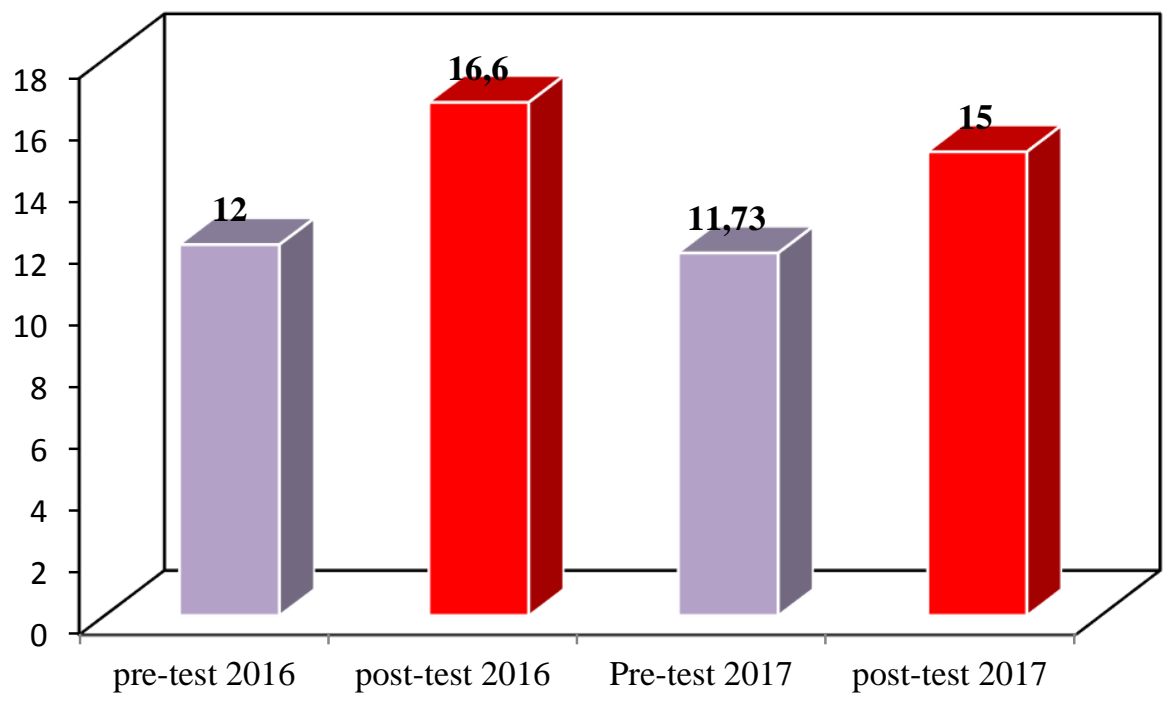

Gambar 2. Perbandingan Tingkat Pengetahuan Mahasiswa Non Kesehatan Sebelum dan Sesudah Membaca Leaflet

Pada kuesioner yang diberikan sebanyak 20 pertanyaan secara keseluruhan banyak responden yang menjawab salah mengenai logo obat dan golongan obat apa saja yang dapat diperoleh ketika melakukan swamedikasi dan termasuk juga mengenai pembelian antibiotik pada saat mahasiswa belum diberikan edukasi dengan leaflet, dimana dalam presepsi mereka antibiotik dapat diperoleh tanpa resep dokter dalam bentuk sediaan tablet maupun dalam bentuk topikal (dioleskan pada permukaan kulit) yaitu salep tetapi tidak semua antibiotik dapat diperoleh dengan resep dokter, hanya pada sediaan antibiotik berbentuk salep yang dapat diperoleh tanpa resep dokter, karena ntibiotik dalam bentuk salep termasuk obat keras dalam golongan OWA (obat wajib apotek). Selain antibiotik dalam bentuk topikal, golongan obat keras yang termasuk dalam OWA juga dapat diperolah tanpa perlu resep dokter.

Tingkat pengetahuan dalam swamedikasi yang rendah menyebabkan banyak kesalahan dalam melakukan swamedikasi salah satunya yaitu penggunaan obat yang tidak rasional. Penggunaan obat yang rasional adalah bila pasien menerima obat yang sesuai dengan kebutuhan klinis, dosis yang sesuai, dengan waktu yang adekuat dengan biaya yang terendah bagi pasien dan masyarakat. Penggunaan obat yang tidak rasional merupakan masalah besar di seluruh dunia. Berdasarkan data dari WHO lebih dari $50 \%$ obat-obatan yang diresepkan, diserahkan atau dijual tidak rasional, dan setengah dari seluruh pasien gagal mendapatkan obat-obatan yang sesuai untuk mereka ${ }^{[12]}$.

Swamedikasi yang tidak sesuai aturan akan menyebabkan efek yang serius seperti timbulnya reaksi efek samping obat dan resistensi antibiotik. Kesalahan pengonsumsian antibiotik dapat memicu terjadinya resistensi antibiotik. WHO mengeluarkan data bahwa setidaknya ada 2.049.442 kasus kesakitan karena resistensi antibiotik dan 23.000 diantaranya meninggal dunia ${ }^{[13]}$. Tingkat pengetahuan dalam swamedikasi yang rendah menyebabkan banyak kesalahan dalam melakukan swamedikasi salah satunya yaitu penggunaan obat 
yang tidak rasional. Penggunaan obat yang rasional adalah bila pasien menerima obat yang sesuai dengan kebutuhan klinis, dosis yang sesuai, dengan waktu yang adekuat dengan biaya yang terendah bagi pasien dan masyarakat.

Faktor-faktor yang penyebab terjadinya penggunaan obat yang tidak rasional antara lain yaitu kurangnya informasi, kesalahan dan kurangnya pendidikan dan latihan bagi tenaga kesehatan, kurangnya komunikasi tenaga kesehatan dengan pasien, kurangnya fasilitas, diagnosis yang tidak tepat, permintaan pasien, tidak efektifnya regulasi obat, aktivitas promosi dari industri farmasi yang berlebihan ${ }^{[14]}$. Dengan dilakukannya penelitian ini mahasiswa jadi lebih mengetahui tentang perbedaan obat-obat yang dapat digunakan secara swamedikasi melalui logo obat yaitu obat bebas dan obat bebas terbatas serta OWA (obat wajib apotek) yang dapat diperoleh tanpa resep dokter karena penggunaan obat bebas dan obat bebas terbatas maupun OWA yang sesuai dengan aturan dan kondisi penderita akan mendukung upaya penggunaan obat yang rasional $^{[15 .]}$

\section{KESIMPULAN}

Berdasarkan hasil dari pengaruh penggunaan leaflet terhadap tingkat pengetahuan mahasiswa terhadap swamedikasi yang telah dilakukan dapat disimpulkan bahwa terjadi peningkatan jumlah jawaban benar pada posttest dan terdapat perbedaan signifikansi pengetahuan setelah membaca leaflet. Mahasiswa kesehatan memiliki pengetahuan yang lebih baik jika dibandingkan dengan mahasiswa non kesehatan namun memiliki $\mathrm{P}($ value $)$ yang sama yaitu 0,000 begitu pula dengan perbedaan tingkat pengetahuan mahasiswa jika dilihat dari angkatannya, angkatan 2016 memiliki tingkat pengetahuan lebih tinggi dibandingkan dengan angkatan 2017. Pengaruh leaflet sebagai media edukasi juga cukup baik dan pemberian edukasi melalui cara ini terbilang cukup efektif dalam meningkatkan ilmu pengetahuan.

\section{DAFTAR PUSTAKA}

[1] Nur,Aini, Harahap, Khairunnisa, Juanita, Tanuwijaya.2017.Tingkat Pengetahuan Pasien dan Rasionalitas Swamedikasi di Tiga Apotek Kota Panyabungan. Jurnal Sains Farmasi \& Klinis (p- ISSN: 2407-7062 | eISSN: 2442-5435)

[2] Pratiwi Puji Ningrum, Liza Pristianty, Gusti Noorrizka Anila Impian. 2014. Pengaruh Pengetahuan Terhadap Perilaku Swamedikasi Obat Anti-Inflamasi Non-Steroid Oral pada Etnis Thionghoa di Surabaya. Jurnal Farmasi Komunitas Vol. 1, No. 2, (2014) 36-40

[3] Departemen Kesehatan RI. 2008. Profil kesehatan Indonesia 2007. Jakarta : Depkes RI Jakarta.

[4] Muharni, S., Fina, A., dan Maysharah, M. (2015). Gambaran Tenaga Kefarmasian dalam Memberikan Informasi Kepada Pelaku Swamedikasi di ApotekApotek Kecamatan Tampan, Pekanbaru. Jurnal Sains Farmasi \& Klinis.

[5] Kemenkes. Rencana Strategis Kementerian Kesehatan Tahun 20152019. Jakarta: Kementerian Kesehatan RI; 2015.

[6] Sharif, Suleiman I. 2014. SelfMedication Among Non- Healthcare Students Of University Of Sharjah, $U A E$. Unit Emirat Arab: Sharjah University

[7] Sharif, Suleiman I. 2015. SelfMedication Practice Among Pharmacists in UAE. Unit Emirat Arab: Sharjah University.

[8] Azali, Lalu M Panji. 2014. Perbandingan Gambaran Perilaku Self Medication Pada Mahasiswa Semester 8 Program Studi Ilmu Keperawatan, Kedokteran Gigi, Dan 
Farmasi FKIK Universitas

Muhammadiyah Yogyakarta.

Yogyakarta: Universitas

Muhammadiyah Yogyakarta.

[9] Wawan A, Dewi M, 2010, Teori Dan Pengukuran Pengetahuan, SikapDan Perilaku Manusia, Nuha Medika, Yogyakarta.

[10]Da Silva M.G.C., Soares M.C.F., Mucillo-Baisch A.L., 2012,SelfMedication In University Students From the City of Rio Grande, Brazil. BMC Public Health, 12:339.

[11]Notoatmodjo, S: Metodologi Penelitian Kesehatan, Rineka Cipta, Jakarta, 2002, p32
[12]WHO; 2014 Maternal Mortality: World Health Organization.

[13]WHO. 2013. Antibiotic Resistance Threats in the United States. USA: US Department of Health and Human Services. USA: World Health Organization.

[14] Ambwani, S. \& Mathur, A.K., 2006. Rational drug use (Chapter-2). Health Administrator. 19(1): 5-7.

[15]Kristina, dkk., 2008, Perilaku Pengobatan Sendiri yang Rasional pada Masyaarkat Kecamatan Depok dan Cangkringan Kabupaten sleman. 